\title{
Teaching system for pantomime artist Jemek Supardi for prospective Pantomime artists in Yogyakarta
}

\author{
Indar Sabri ${ }^{1}$, Muhammad Jazuli ${ }^{2}$, TotokSumaryanto $\mathrm{F}^{3}$ and Autar Abdillah ${ }^{4}$ \\ \{indarsabri@unesa.ac.id ${ }^{1}$, muhjaz61@ @mail.com² \\ autarabdillah@unesa.ac.id $\left.{ }^{4}\right\}$ \\ Postgraduate program at Universitas Negeri Semarang and Unesa ${ }^{1}$, Universitas Negeri Semarang ${ }^{2,3}$, \\ Universitas Negeri Surabaya ${ }^{4}$
}

\begin{abstract}
This research is based on the development of pantomime art in Indonesia, especially in Yogyakarta, which has pantomime artists Jemek Supardi. as an Indonesian pantomime artist, Jemek Supardi played a role in the progress of the development of pantomime in Yogyakarta. The transmission of Jemek Supardi's art or teaching to prospective artists or the so-called young Yogyakarta pantomimer is interesting because Jemek Supardi himself is a self-taught artist. This study aims to find a system of art or teaching transmission carried out by Jemek Supardi to prospective Yogyakarta mime artists. This study uses qualitative methods, data obtained using interview and observation techniques. The object of research is Jemek Supardi and prospective pantomime artists/students. The results of the study found that the system of art or teaching transmission carried out by Jemek Supardi used a system of principles / attitudes and sanggar systems.
\end{abstract}

Keywords: Teaching system, Pantomime and Jemek Supardi

\section{Introduction}

Mime art is an art that is not from Indonesia, a long history of pantomime from India-Egypt to Greece and the Renaissance era is a long story of pantomime, seen from the form of its performances, pantomime art including the field of Theater art with elements of power in art role and body. In Indonesia the existence of pantomime art has existed for a long time but its development is not significant. Aristotle in Poetics provides pantomime understanding with basic characteristics born of human activities due to imitating motion that is not predominantly based on rhythm. So the art of body movement is manifested as a gesture, so the performance art is called pantomime[1]. The term pantomime comes from the Greek word which means all signs. Etymologically, the pantomime performance known until now is a show that does not use verbal language. The show can even be completely soundless. Clearly, mime is a silent show[2]. Pantomime is body art and expression that tells a story without words with the illusion of forms built by pantomime through visualization of objects without objects[3]. Pantomime is a motion drama that prioritizes humor. Even though there are several meanings in it, they are delivered with funny movements. Pantomime is one form of art that will direct someone to become a quality actor. By understanding and training Pantomime, prospective actors will be able to be perfect in their profession, he will at least please the eyes if he wants to practice Pantomime[4]. From a number of expert experts above regarding pantomime art, it can be seen that the existence of pantomime art has long been important and the importance of pantomime art has 
been studied for prospective theater actors and even the need for mime art was developed with the emergence of young artists who chose pantomime as the center of study or art.

Factors causing the lack of development of pantomime artifacts significantly in Indonesia are first, the lack of popularity of pantomime art in Indonesia so that many people do not know about pantomime art. Second, the lack of artists who decided to pursue pantomime art was noted by several Indonesian artists who had played pantomime such as Didi Petet, Moertri Purnomo and Azwar AN but the intensity of art in the world of pantomime was minimal, they were more active in the theater and film. Indonesian pantomime artists whose intensity in the arts in the old pantomime world included Yayu Anru, Sena Utoyo, Septian Dwi Cahyo and Jemek Supardi. Third, the lack of regeneration programs undertaken by Indonesian pantomime artists.

The three factors that cause the lack of development of pantomime art in Indonesia are the authors' attention to be presented and reviewed in a study. The research this time focused on the problem of the lack of regeneration carried out by Indonesian pantomime artists in an effort to produce young artists so that the development of pantomime art can run with the market. The researcher was interested in Jemek Supardi, a mime artist from the Special Region of Yogyakarta (DIY), by looking at the phenomenon that Jemek Supardi as an autonomous artist did not try to regenerate pantomime artists in DIY.

The existence of Jemek Supardi in the world of performing arts in Indonesia is undoubtedly the copolymer of the mime artist Jemek Supardi, who has been engaged in pantomime since the 1970s, which earned him many awards, as "Father of Indonesian Pantomime" inherent in him. The artist who dedicated his life to the development of pantomime art in Indonesia said that regeneration was done by mentioning several names of young pantomime artists in DIY such as Muh.Arif Wijayanto alias Broto wijayanto and Asita kaladewa. [5] This study focuses on the study of the Pantomime Artists Learning System of Jemek Supardi at the Pantomime Artists Candidate in Yogyakarta. walk. The concept of art education is used as an approach to explore the learning system carried out by Jemek Supardi. In this case, art education is the most potential means to inherit values from one generation to the next. Rohidi states that culture cannot be inherited "genetically", but is transferred from one generation to the next. [6] In line with UNESCO at the International Conference on Arts Education, it produced a Road Map for Art Education, understanding that the potential of creativity and cultural diversity are two very important things in the function of art education. It is a rational principle to increase interest in art education as an important component in educational programs. [7]

\section{Method}

This research is a qualitative descriptive study with an approach to the concept of art education. The data sources in this study were Jemek Supardi, mime artist, and student. Data collection techniques are carried out by observation, interviews and documentation. Data analysis is carried out with the aim of the collected data being analyzed into an embodiment that can be understood through a logical and systematic description.

\section{Results and Discussion}

The definition of art education is a conscious effort to prepare students through activities of guidance, teaching, and / or training in order to be able to master the ability of art in 
accordance with the role that must be played. This art education system at the beginning of its history, the process was based largely on the applicant, studio, or studio system and then shifted to the academic system of education. The art education system consists of two models: art education is functioned to transmit artistic talent to generations, whose aim is to produce an expert in the field of art (artist) with the principle of education in art (education in arts). The second function of art is the purpose of utilizing the art of means to help develop individual students in order to prepare for the future. This is what is called the function of art as an educational asset or function of art education (education through arts). [8] The Art Transmission System itself is divided into four systems, namely: the principle / enumeration system, inheritance system, academy system, studio and self-taught system.

Based on the data obtained and the concept of research art education converged on the results that Pantomime Artists Jemek Supardi used the art education system with the Transmission model, while the system used was the principle / enumeration system and studio system.

\subsection{Apretinsip/pencantrikan system}

The application system in art education is the organization of teaching component devices or art training consisting of a number of components. These components are master artists as trainers or instructors and students or students as aprentis and art procedures as the material being taught. The master artist is the name of the artist given by the community because it has a broad quality and level of art. The characteristic of a master is having the motivation to pass on his skills in art to other people, especially aspiring artists without having to worry about getting a rival. Aprentis is a term for prospective artists or students. In the puppet story the aprentices are identical to the cantric designations because they have the same characteristics. At the moment, in accepting orders or instructions from the master, the cantric should do it with joy and obey without the slightest resistance. A cantilever should also have strong and potentially proprietary motivation for the work done. Artistic procedures are teaching materials that are transmitted from the master to the apprentice. Teaching materials are taken from the masters' proficiency based on their personal experience mastered since abilities are in the form of basic skills, advanced skills, and mature or proficiency skills.

The existence of Jemek Supardi in the world of performing arts in Indonesia is undoubtedly the copolymer of the mime artist Jemek Supardi, who has been engaged in pantomime since the 1970s, which earned him many awards, as "Father of Indonesian Pantomime" inherent in him. The artist who dedicated his life to the development of pantomime art in Indonesia said that regeneration was done by mentioning several names of young pantomime artists in DIY such as Muh.Arif Wijayanto alias Broto wijayanto and Asita kaladewa.

Since studying at the Yogyakarta Academy of Drama and Film, Broto Wijayanto knows the art of pantomime from the first two teachers who are full-time teachers as lecturers who taught him on campus and Jemek Supardi as a teacher where Broto studied pantomime in an interesting way. The principle / enrollment system was carried out by Broto through a joint process with Jemek Supardi in the works created by Jemek Supardi [9]. The author gets the broto wijayanto data playing with Jemek Suprdi in various works including exodos, 50th Jemek Supardi, dead eyes, until the performance of ngilogitok in 2017 ago. Mas Jemek is my teacher even though it does not admire formal knowledge, but the knowledge given to me during the process is very much. [10] Whereas Asita Kala Dewa was one of the students recognized by Jemek Supardi who received pantomime knowledge since he attended the Indonesian Art Institute and joined the Yogyakarta Pantomime Workshop with Broto. The nyantrik system was 
carried out to Jemek Supardi and was involved in several works such as the 50th Jemek Supardi, dead eyes, surgeons and Ngilogitok.

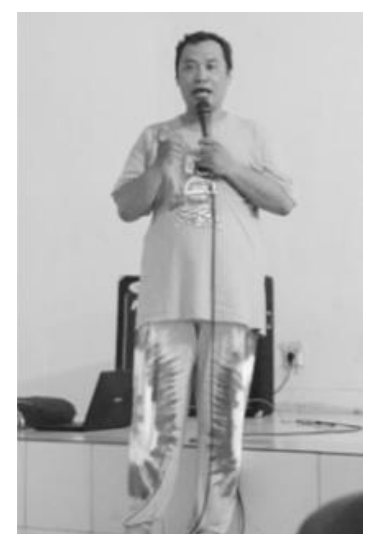

Figure 1. Broto Wijayanto

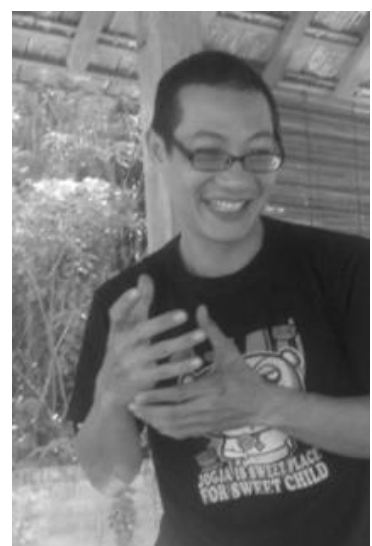

Figure 2. Asita Kaladewa

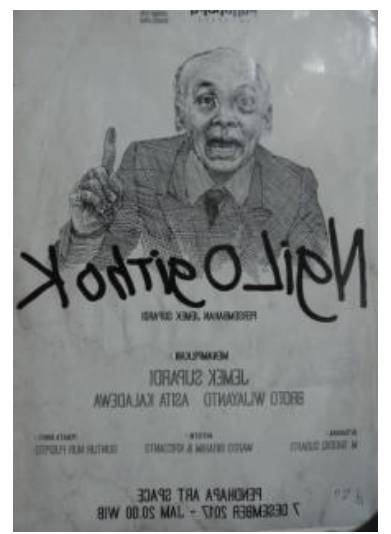

Figure 2 Poster Ngilogitok 


\subsection{Sanggar System}

The studio system is an art education system whose transmission process takes place through exchanging experiences by studio members. This process occurs programmatically as well as an artistic or academic system of education. However, it can also be programmed trinya the process of interaction between transmitters and contracting occurs without planned by both parties. Sometimes what happens is that outsiders secretly adopt some of the performance of contagion artists who are fellow members of the staff. This is an infection called informal art education. "Studio is a place for activities to help support the success of mastering success". [11] Studio is a meeting place attended by a group of people or people who are usually held regularly and periodically to conduct research, discussion, discussion activities on certain fields. Sanggar is an out-of-school education, namely education that is accepted in the family, in an institution that is not in the form of a school or community. [12]

In 2015 Jemek Supardi had a pantomime class with Jemek Supardi who was part of the Sekar kinanti Art Studio which is a studio owned by his own daughter. Some students enrolled and studied directly with Jemek Supardi, in addition to the jemek supardi in the class Asita and several other students who got knowledge from Jemek Supardi through the Apret principals / enrollment system also helped teach students in the pantomime class of Jemek Supardi.

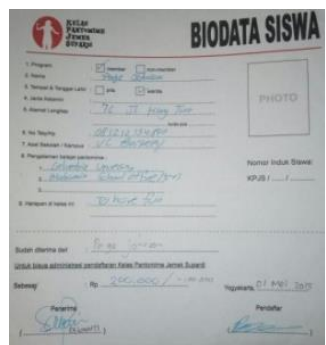

Figure 4. Student registration form in the Jemek Supardi pantomime class

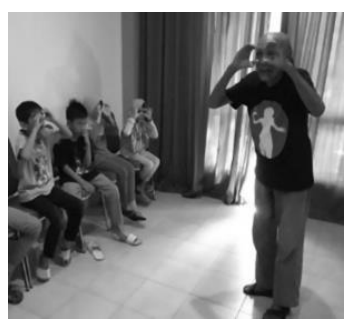

Figure 5. Jemek Supardi is teaching

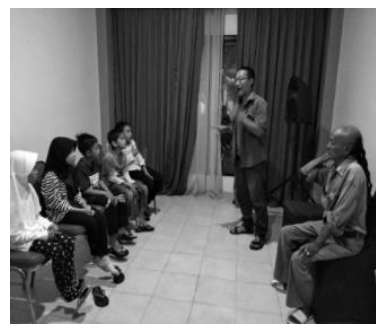

Figure 6. Asita Kaladewa as a teaching assistant 
In addition to the pantomime class, Jemek Supardi also often cooperates with the Yogyakarta Education Office and other related agencies as resource persons to train several outstanding students in Yogyakarta both in the face of competitions and as an aesthetic experience for students from an early age to know pantomime so that the pantomime art is increasingly rapid its development in Indonesia.

\section{Conclusion}

The main problem of the lack of development of pantomime art in Indonesia is the lack of pantomime art learning forums and the awareness of Indonesian Pantomime Artists who are considered as masters to carry out regenersi on young pantomime artists. Jemek Supardi as an Indonesian pantomime artist who is not an autodidact artist has thought about regenerating his young pantomime players in Yogyakarta. Jemek Suprdi uses the concept of art education by using the principle / enlightenment learning system and studio learning system in the regeneration process of young pantomime artists in Yogyakarta . 


\section{References}

[1] Richard, Levin. Tragedy: Plays, Theory, and Criticism, New York: Harcourt Brace Javanovich,Inc (1960)

[2] Soemanto, Bakdi. Jagat Teater. Yogyakarta: Media Pressindo (2001)

[3] Sabri, Indar dan Welly Suryandoko, Seni Pantomim Menjadi Pantomimer, Surabaya: Unesa press. (2014)

[4] Iswantara, N. Wajah pantomim Indonesia. Jogja: Media Kreatifa (2007).

[5] Suhaya, Pendidikan Seni Sebagai Penunjang Kreativitas. Jurnal Pendidikan dan Kajian Seni, Vol.1, No.1, qq.1-15 (2016)

[6] Rohidi, Tjetjep R. Kesenian dalam Pendekatan kebudayaan. Bandung: STISI Bandung.( 2000)

[7] UNESCO. "Road Map for Arts Education". The World Conference on Arts Education: Building Creative Capacities for the 21 st Century, Lisbon, March 6, (2006).

[8] Iryanti, V. Eny, Jazuli, M. Wacana Pendidikan Seni. Harmonia Jurnal Pengetahuan Dan Pemikiran Seni, vol 2 issue 2 qq.40-48, (2001)

[9] Fuller, AlisonUnwin, Lorna. Learning as Apprentices in the Contemporary UK Workplace: creating and managing expansive and restrictive participation. Journal of Education and Work vol.16 issue 4 qq.407-426 (2003).

[10] Guile, David Young, Michael. Apprenticeship as a conceptual basis for a social theory of learning. Journal of Vocational Education and Training.Vol 50 issue 2 qq.173-192 (1998)

[11] Khutniah, Nainul. "Upaya Mempertahankan Eksistensi Tari Krida Jati di Sanggar Hayu Budaya Kelurahan Pergol Jepara”. Jurnal Seni Tari. 1, (1),12. (2012)

[12] Koentjaraningrat. 1984. Antropologi Sosial. Jakarta: Dian Rakyat. (1984) 